새로운 베스타틴 유사체의 입체선택적 합성

\author{
서영란 · 이수범 · 김영규 ${ }^{\dagger}$ \\ 서울대학교 공과대학 화학생물공학부 \\ (2014년 12월 22일 접수, 2015년 1월 7일 심사, 2015년 1월 15일 채택)

\section{Stereoselective Synthesis of Novel Bestatin Analogs}

\author{
Youngran Seo, SooBeom Lee, and Young Gyu Kim ${ }^{\dagger}$ \\ Department of Chemical and Biological Engineering, Seoul National University, Seoul 151-742 \\ (Received December 22, 2014; Revised January 7, 2015; Accepted January 15, 2015)
}

\begin{abstract}
초록
두 종류의 새로운 베스타틴(bestatin) 유사체를 D-leucine과 D-valine으로부터 효율적이면서 입체선택적으로 합성하였다. 아미노펩티데이즈 억제제인 베스타틴은 면역조절 효과를 보이며 급성백혈병 치료제로 상품화되어 있다. 주요 중간체 인 trans-옥사졸리딘 메틸에스터 $\mathbf{2 a}$ 와 $\mathbf{2 b}$ 는 페닐설포닐나이트로메테인 $\left(\mathrm{PhSO}_{2} \mathrm{CH}_{2} \mathrm{NO}_{2}\right)$ 과 $N$-하이드록시 메틸기가 보호 기로 도입된 $\alpha$-아미노 알데하이드 $(\mathbf{4 a}$ 와 $\mathbf{4 b})$ 간의 일련의 세 단계 연속반응과 연이은 가오존분해 반응으로부터 20 : 1 이상의 입체선택성으로 합성되었다. $\mathbf{2 a}$ 와 $\mathbf{2 b}$ 의 가수분해 반응 후에 L-Leu-OMe와의 펩타이드 결합을 통하여 베스타 틴의 새로운 유사체인 $\mathbf{3 a}$ 와 $\mathbf{3 b}$ 를 보호기가 도입된 형태로 얻었다. 이소부틸기와 이소프로필기를 갖는 두 종류의 새로 운 베스타틴 유사체 $(\mathbf{1 a}$ 와 $\mathbf{1 b}$ )는 해당 $\alpha$-아미노알데하이드 4 로부터 높은 입체선택성으로 6 단계에 걸쳐 각각 $51 \%$ 와 $38 \%$ 의 수율로 합성되었다.
\end{abstract}

\begin{abstract}
Two new analogs of bestatin were prepared from D-leucine and D-valine in a stereoselective and efficient way. An aminopeptidase inhibitor bestatin shows significant biological effects on immunomodulation and is marketed for the treatment of acute myelocytic leukemia. The key intermediates, trans-oxazolidine methyl esters $\mathbf{2 a}$ and $\mathbf{2 b}$, were obtained with more than 20 to 1 stereoselectivity in a one-pot procedure by the three cascade reactions between $N$-hydroxymethyl protected $\alpha$-amino aldehydes (4a and 4b) and phenylsulfonylnitromethane $\left(\mathrm{PhSO}_{2} \mathrm{CH}_{2} \mathrm{NO}_{2}\right)$ and the following in-situ ozonolysis. Basic hydrolysis of $\mathbf{2 a}$ and $\mathbf{2 b}$, and then the peptide coupling with L-Leu-OMe produced the protected derivatives of two new bestatin analogs, 3a and $\mathbf{3 b}$, respectively. The new isobutyl and isopropyl analogs of bestatin (1a and $\mathbf{1 b})$ were produced in overall $51 \%$ and $38 \%$ yields, respectively, with high stereoselectivity from the corresponding protected $\alpha$-amino aldehydes 4 in a six-step process.
\end{abstract}

Keywords: bestatin analogs, aminopeptidase inhibitor, $\beta$-amino- $\alpha$-hydroxy acid, intramolecular conjugate addition.

\section{Introduction}

Aminopeptidase N (APN), a metal-dependent membrane-bound protease, has been studied as a useful clinical marker because its overexpression affects the protein activation, degradation, and regulation that are closely related to the inflammatory diseases and cancers[1-4]. In order to control the overexpression of APN, several naturally occurring aminopeptidase inhibitors have been developed from microbial culture filtrates. Bestatin, first isolated from a culture filtrate of Streptomyces olivoreticuli (MD976-C7)[5], has been extensively stud-

† Corresponding Author: Seoul National University,

Department of Chemical and Biological Engineering, Seoul 151-742

Tel: +82-2-880-8347 e-mail: ygkim@snu.ac.kr

pISSN: 1225-0112 eISSN: 2288-4505@ 2014 The Korean Society of Industrial and Engineering Chemistry. All rights reserved. ied due to its multiple effects on the immune system, and it has been used to treat acute myelocytic leukemia under a trade name of Ubenimex[6]. For the structure-activity relationship, its analogs have been synthesized (Figure 1(a))[7-10], which has revealed that the threo- $\beta$-amino- $\alpha$-hydroxy acid moiety in bestatin interacts with the active site of aminopeptidase $\mathrm{N}[11]$.

The bioactive vicinal amino hydroxy acid unit is also widely found in other naturally occurring aminopeptidase inhibitors. For example, amastatin isolated also from the culture filtrate of Stereptomyces sp.[12] contains (2R,3S)-3-amino-2-hydroxy-5-methylhexanoic acid (AHMHA) at the N-terminus (Figure 1(b)), and 3-amino-2-hydroxy-4-methylpentanoic acid (AHMPA) is embedded in lapstatin although its stereochemistry has not been established yet (Figure 1 (c))[13].

In order to demonstrate the effects of the side chain at the threo-vicinal amino hydroxy acid unit on the bioactivity, we planned to substitute the benzyl group at the N-terminus of bestatin with an isobutyl 
<smiles>[R1]c1ccc(CC(N)C([R])C([R])NC(CC(C)C)C(=O)O)cc1</smiles>

bestatin $\left(\mathrm{R}^{1}=\mathrm{H}, \mathrm{R}^{2}=\mathrm{OH}, \mathrm{X}=\mathrm{O}\right)$ $p$-hydroxybestatin $\left(\mathrm{R}^{1}=\mathrm{OH}, \mathrm{R}^{2}=\mathrm{OH}, \mathrm{X}=\mathrm{O}\right)$ $p$-nitrobestatin $\left(\mathrm{R}^{1}=\mathrm{NO}_{2}, \mathrm{R}^{2}=\mathrm{OH}, \mathrm{X}=\mathrm{O}\right)$ $\alpha$-thiobestatin $\left(\mathrm{R}^{1}=\mathrm{H}, \mathrm{R}^{2}=\mathrm{SH}, \mathrm{X}=\mathrm{O}\right)$ bestatin thioamide $\left(\mathrm{R}^{1}=\mathrm{H}, \mathrm{R}^{2}=\mathrm{OH}, \mathrm{X}=\mathrm{S}\right)$

(a) bestatin and its analogs

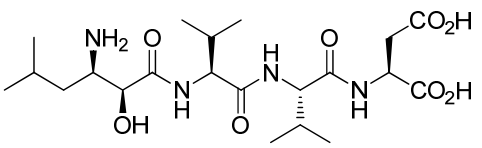

(b) amastatin

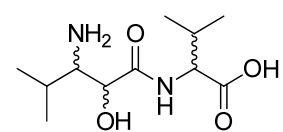

(c) lapstatin
Figure 1. The structure of natural or unnatural aminopeptidase inhibitors.

or isopropyl group, which are present in amastatin or lapstatin, respectively (Figure 1). To the best of our knowledge, this is the first synthetic report for isobutyl or isopropyl substituted bestatin analogs (Figure 2).

\section{Experimental}

\subsection{General}

Materials were obtained from commercial suppliers and were used without further purification. Methylene chloride was distilled from calcium hydride immediately prior to use. Air or moisture sensitive reactions were conducted under nitrogen atmosphere using oven-dried glassware and standard syringe/septa techniques. The reactions were monitored with a $\mathrm{SiO}_{2}$ TLC plate under UV light $(254 \mathrm{~nm})$ and by visualization with a ninhydrin staining solution. Column chromatography was performed on silica gel 60 (70-230 mesh). Melting point was measured on a Meltemp apparatus in open capillary tubes. Optical rotations were determined at ambient temperature with a digital polarimeter and are the average of ten measurements. ${ }^{1} \mathrm{H}$ and ${ }^{13} \mathrm{C}$ NMR spectra were measured at $400 \mathrm{MHz}$ and $100 \mathrm{MHz}$, respectively in $\mathrm{CDCl}_{3}$ or $\mathrm{MeOH}-d_{4}$. The ${ }^{1} \mathrm{H}$ NMR spectral data were reported as follows in ppm $(\delta$ ) from the internal standard (TMS, $0.0 \mathrm{ppm}$ ): chemical shift (multiplicity, integration, coupling constant in $\mathrm{Hz}$ ). The ${ }^{13} \mathrm{C}$ NMR spectra were referenced with the 77.16 resonance of $\mathrm{CDCl}_{3}, 49.00$ resonance of $\mathrm{MeOH}-d_{4}$. Low and high resolution mass spectra were measured by the $\mathrm{CI}$ or $\mathrm{FAB}$ ionization method and analyzed by magnetic sector mass analyzer.

\subsection{General procedure for trans-oxazolidine methyl esters 2}

To $\alpha$-amino aldehyde $4 a\left(\mathrm{R}^{1}=\mathrm{i}-\mathrm{Bu}, 646 \mathrm{mg}, 2.63 \mathrm{mmol}\right)$ in THF (2 mL) was added phenylsulfonylnitromethane $(636 \mathrm{mg}, 3.16 \mathrm{mmol})$ and DMAP (482 $\mathrm{mg}, 3.95 \mathrm{mmol}$ ). The reaction mixture was stirred at room temperature for 2 days with vigorous stirring until the starting material 4a disappeared. The mixture was diluted with THF $(5 \mathrm{~mL})$ and methanol $(5 \mathrm{~mL})$, to which was added DBU $(1.19 \mathrm{~mL}, 7.90 \mathrm{mmol})$ at room temperature. Then, the reaction mixture was cooled to $-78{ }^{\circ} \mathrm{C}$, and ozone was bubbled through over $30 \mathrm{~min}$. After quenching the reaction with acetic acid $(1 \mathrm{~mL})$, the resulting mixture was warmed up to room temperature. After removing the solvent under reduced pres-<smiles>CC(C)C[C@H](N)[C@H](O)C(=O)NC(C(=O)O)C(=O)O</smiles>

$1 \mathrm{a}$<smiles>CC(C)[C@H](N)[C@H](O)C(=O)NC(C(=O)O)C(=O)O</smiles>

$1 b$
Figure 2. New bestatin analogs.

sure, the residue was partitioned between EtOAc $(20 \mathrm{~mL})$ and an aqueous saturated solution of $\mathrm{NH}_{4} \mathrm{Cl}(30 \mathrm{~mL})$. The aqueous layer was extracted with EtOAc $(20 \mathrm{~mL} \times 3)$, and the combined organic layers were dried over $\mathrm{MgSO}_{4}$, filtered, and concentrated under reduced pressure. The organic residue was purified by silica gel chromatography (hexane : EtOAc $=8: 1)$ to afford the desired ester $2 \mathbf{a}(546 \mathrm{mg}$, $1.90 \mathrm{mmol}, 72 \%$ ) as a colorless oil.

2a : 3-tert-Butyl 5-methyl (4R,5S)-4-isobutyloxazolidine-3,5-dicarboxylate : Yield 72\% (546 mg); colorless oil; $[\alpha]_{\mathrm{D}}^{16}=+5.8(c=$ 2.8, $\left.\mathrm{CHCl}_{3}\right) ;{ }^{1} \mathrm{H}$ NMR $\delta 0.99(\mathrm{~d}, 3 \mathrm{H}, J=6.4), 1.01$ (d, 3H, $\left.J=6.4\right)$, $1.44-1.50(\mathrm{~m}, 1 \mathrm{H}), 1.48(\mathrm{~s}, 9 \mathrm{H}), 1.60(\mathrm{~m}, 1 \mathrm{H}), 1.69(\mathrm{~m}, 1 \mathrm{H}), 3.79(\mathrm{~s}$, $3 \mathrm{H}), 4.24$ (br s, 1H), 4.37 (d, 1H, $J=1.6), 4.85$ (d, $1 \mathrm{H}, J=3.6), 5.28$ (s, $1 \mathrm{H}) ;{ }^{13} \mathrm{C}$ NMR $\delta \quad 22.1,22.8,25.2,28.3,42.2,52.3,57.8,79.0$, $79.0,80.6,152.8,171.4$.

2b : 3-tert-Butyl 5-methyl $(4 R, 5 S)$-4-isopropyloxazolidine-3,5-dicarboxylate : $50 \%(415 \mathrm{mg})$, colorless oil; $[\alpha]_{\mathrm{D}}^{16}=+10.5(c=0.64$, $\left.\mathrm{CHCl}_{3}\right) ;{ }^{1} \mathrm{H}$ NMR $\delta 0.94(\mathrm{~d}, 3 \mathrm{H}, J=7.0), 0.96(\mathrm{~d}, 3 \mathrm{H}, J=7.0), 1.44$ (s, 9H), 1.48 (m, 1H), 3.46 (s, 3H), 3.74 (br s, 1H), 4.44 (s, 1H), 4.80 $\left(\mathrm{d}, 1 \mathrm{H}, J=3.2\right.$ ), 5.23 (br s, $1 \mathrm{H}$ ); ${ }^{13} \mathrm{C}$ NMR $\delta 17.8,18.9,28.3,31.0$, 52.4, 64.6, 76.8, 80.0, 80.8, 153.3, 171.9 .

\subsection{General procedure for dipeptide derivatives 3}

To $2 \mathrm{a}\left(\mathrm{R}^{1}=\mathrm{i}\right.$-Bu, $\left.753 \mathrm{mg}, 2.62 \mathrm{mmol}\right)$ in THF $(6 \mathrm{~mL})$ at $0{ }^{\circ} \mathrm{C}$ was added $2 \mathrm{~N} \mathrm{NaOH}(6 \mathrm{~mL})$. After the reaction mixture was stirred at room temperature for $1 \mathrm{~h}$, it was acidified with $2 \mathrm{~N}$ aq. $\mathrm{HCl}$ to $\mathrm{pH}$ 1 at $0{ }^{\circ} \mathrm{C}$. The resulting mixture was then partitioned between EtOAc $(20 \mathrm{~mL})$ and brine $(5 \mathrm{~mL})$. The aqueous phase was extracted with EtOAc $(20 \mathrm{~mL} \times 2)$, and the combined organic layers were dried over $\mathrm{MgSO}_{4}$, filtered and concentrated under reduced pressure to give crude $\mathbf{2 a}$.

To crude $2 \mathrm{a}$ in THF $(10 \mathrm{~mL})$ at $0{ }^{\circ} \mathrm{C}$, HOBt $(203 \mathrm{mg}, 1.50 \mathrm{mmol})$ and L-Leu-OMe $(250 \mathrm{mg}, 1.38 \mathrm{mmol})$ were added. Then, EDC $\cdot \mathrm{HCl}$ (288 $\mathrm{mg}, 1.50 \mathrm{mmol})$, and $N, N$-diisopropylethylamine $(44 \mu \mathrm{L}, 3.13$ mmol) were added to the reaction mixture. The mixture was stirred at room temperature overnight. After the removal of the solvent, the residue was partitioned between a saturated aq. solution of $\mathrm{NH}_{4} \mathrm{Cl}(20 \mathrm{~mL})$ and EtOAc $(20 \mathrm{~mL})$. The aqueous phase was extracted with EtOAc $(20$ $\mathrm{mL} \times 2$ ), and the combined organic layers were dried over $\mathrm{MgSO}_{4}$, filtered and concentrated under reduced pressure. The organic residue was purified by silica gel chromatography (hexane : EtOAc $=8: 1$ ) to afford the dipeptide intermediate $\mathbf{3 a}$ as a colorless oil.

3a : [3-tert-Butyl 5-methyl $(4 R, 5 S)$-4-isobutyloxazolidine-5-carboxylic acid]-L-leucine methyl ester : Yield $74 \%(370 \mathrm{mg}) ;[\alpha]_{\mathrm{D}}^{10}=-17.4$ $\left(c=0.88, \mathrm{CHCl}_{3}\right)$; colorless oil; ${ }^{1} \mathrm{H} \mathrm{NMR} \delta 0.94(\mathrm{dd}, 6 \mathrm{H}, J=2.8$, 6.2), $1.00(\mathrm{t}, 6 \mathrm{H}, J=6.4), 1.47(\mathrm{~s}, 9 \mathrm{H}), 1.54-1.63(\mathrm{~m}, 3 \mathrm{H}), 1.66-1.77$ 

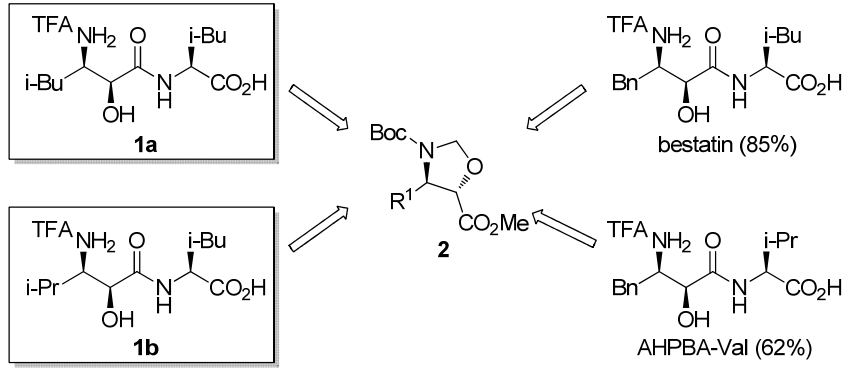

Figure 3. Dipeptide synthesis from trans-oxazolidine methyl esters 2.

(m, 2H), $3.76(\mathrm{~s}, 3 \mathrm{H}), 4.22(\mathrm{~d}, 1 \mathrm{H}, J=2.8), 4.38(\mathrm{dt}, 1 \mathrm{H}, J=2.5$, 7.3), 4.61-4.65 (m, 1H), 4.77 (d, 1H, $J=4.8), 5.31$ (d, $1 \mathrm{H}, J=3.2$ ), $6.86(\mathrm{~d}, 1 \mathrm{H}, J=8.4) ;{ }^{13} \mathrm{C} \mathrm{NMR} \delta 21.9,22.4,22.8,24.9,25.0,28.3$, 41.4, 42.7, 50.3, 52.3, 57.9, 78.2, 80.9, 81.7, 152.9, 170.4, 172.9; HRMS (CI) calcd for $\mathrm{C}_{20} \mathrm{H}_{37} \mathrm{~N}_{2} \mathrm{O}_{6} 401.2652\left([\mathrm{M}+\mathrm{H}]^{+}\right)$, found 401.2651 .

3b : [3-tert-Butyl 5-methyl $(4 R, 5 S)$-4-isopropyloxazolidine-5-carboxylic acid]-L-leucine methyl ester : Yield 76\% (264 mg); $[\alpha]_{D}^{10}=-13.7$ $\left(c=0.81, \mathrm{CHCl}_{3}\right)$; colorless oil; ${ }^{1} \mathrm{H} \mathrm{NMR} \delta 0.92(\mathrm{dd}, 6 \mathrm{H}, J=1.6$, 6.4), 0.99 (t, $6 \mathrm{H}, J=7.0), 1.45$ (s, 9H), 1.54-1.61 (m, 2H), 1.63-1.69 $(\mathrm{m}, 1 \mathrm{H}), 1.94-1.99(\mathrm{~m}, 1 \mathrm{H}), 3.74(\mathrm{~s}, 3 \mathrm{H}), 4.10(\mathrm{dd}, 1 \mathrm{H}, J=2.2,6.6)$, $4.34(\mathrm{~d}, 1 \mathrm{H}, J=2.8), 4.59-4.65(\mathrm{~m}, 1 \mathrm{H}), 4.74(\mathrm{~d}, 1 \mathrm{H}, J=4.8), 5.31$ (br s, $1 \mathrm{H}), 6.91(\mathrm{~d}, 1 \mathrm{H}, J=8.4) ;{ }^{13} \mathrm{C}$ NMR $\delta \quad 18.7,18.9,21.9,23.0$, 25.0, 28.3, 31.5, 41.5, 50.4, 52.5, 64.9, 79.3, 81.0, 153.4, 171.0, 173.0; HRMS (FAB) calcd for $\mathrm{C}_{19} \mathrm{H}_{35} \mathrm{~N}_{2} \mathrm{O}_{6} 387.2495\left([\mathrm{M}+\mathrm{H}]^{+}\right)$, found 387.2496 .

\subsection{General procedure for bestatin analogs 1}

To 3a $\left(\mathrm{R}^{1}=\mathrm{i}-\mathrm{Bu}, 370 \mathrm{mg}, 0.92 \mathrm{mmol}\right)$ in $\mathrm{THF}(6 \mathrm{~mL})$ at $0{ }^{\circ} \mathrm{C}$ was added $2 \mathrm{~N} \mathrm{NaOH}(6 \mathrm{~mL})$. After the reaction mixture was stirred at room temperature for $1 \mathrm{~h}$, it was acidified with $2 \mathrm{~N} \mathrm{HCl}$ to $\mathrm{pH} 1$ at $0{ }^{\circ} \mathrm{C}$. The reaction mixture was then partitioned between EtOAc $(20$ $\mathrm{mL})$ and brine $(5 \mathrm{~mL})$. The aqueous phase was extracted with EtOAc $(20 \mathrm{~mL} \times 2)$, and the combined organic layers were dried over $\mathrm{MgSO}_{4}$, filtered and concentrated under reduced pressure.

To the obtained crude in $\mathrm{CH}_{2} \mathrm{Cl}_{2}$ was added trifluoroacetic acid (39 $\mu \mathrm{L}, 5.15 \mathrm{mmol}$ ) and the reaction mixture was reacted at room temperature overnight. After the removal of the solvents, the reaction mixture was diluted with water $(10 \mathrm{~mL})$. The aqueous layer was washed with EtOAc $(10 \mathrm{~mL})$ three times and then the aqueous layer was condensed under reduced pressure to afford bestatin analog 1a as a white solid in $95 \%$ yield.

1a : (2S,3R)-3-Amino-2-hydroxy-5-methylhexanamindo-4-methylpentanoic acid : Yield 95\% (235 mg); Mp. $131{ }^{\circ} \mathrm{C} ;[\alpha]_{\mathrm{D}}^{10}=-20.4(c$ $\left.=2.1, \mathrm{H}_{2} \mathrm{O}\right) ;{ }^{1} \mathrm{H}$ NMR $\left(\mathrm{MeOH}-d_{6}\right) \quad \delta 0.98(\mathrm{~m}, 12 \mathrm{H}), 1.50(\mathrm{~m}, 1 \mathrm{H})$, 1.63-1.77 (m, 5H), 3.50 (br s, 1H), 4.22 (br s, 1H), 4.43-4.46 (m, 1H); ${ }^{13} \mathrm{C}$ NMR $\left(\mathrm{MeOH}-d_{6}\right) \quad \delta \quad 22.0,22.3,22.9,23.3,25.2,26.1,39.2,41.3$, 52.2, 53.3, 71.1, 173.6, 175.7; HRMS (FAB) calcd for $\mathrm{C}_{13} \mathrm{H}_{27} \mathrm{~N}_{2} \mathrm{O}_{4}$ $275.1971\left([\mathrm{M}+\mathrm{H}]^{+}\right)$, found 275.1977 .

1b : (2S,3R)-3-Amino-2-hydroxy-5-methylhexanamindo-4-methylpropanoic acid : colorless film; Yield quant. (223 mg); Mp. $61{ }^{\circ} \mathrm{C}$; $[\alpha]_{\mathrm{D}}^{10}=-28.4\left(c=2.2, \mathrm{H}_{2} \mathrm{O}\right) ;{ }^{1} \mathrm{H}$ NMR $\left(\mathrm{MeOH}-d_{6}\right) \delta 0.97(\mathrm{dd}, 6 \mathrm{H}$,

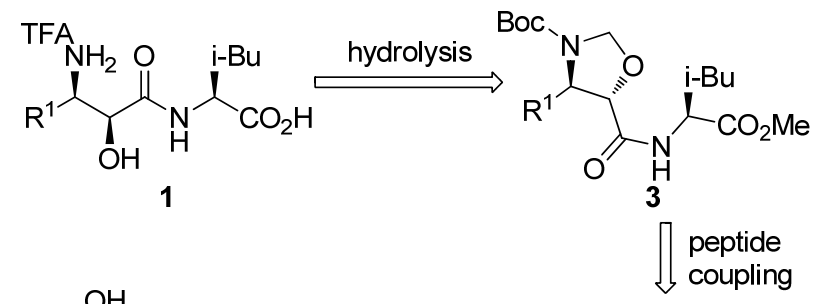

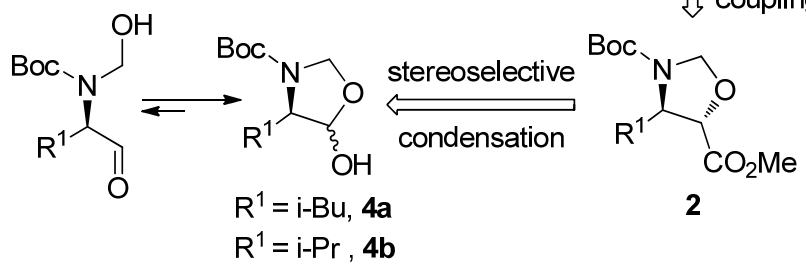

Scheme 1. Retrosynthetic scheme for bestatin analogs.

$J=5.6,9.2), 1.08(\mathrm{~m}, 1.08(\mathrm{~m}, 6 \mathrm{H}), 1.73(\mathrm{~m}, 3 \mathrm{H}), 2.10$ (qt, $1 \mathrm{H}, J$ $=6.7,13.4), 3.2 .3(\mathrm{br} \mathrm{s}, 1 \mathrm{H}), 4.37(\mathrm{~s}, 2 \mathrm{H}), 4.42(\mathrm{~m}, 1 \mathrm{H}) ;{ }^{13} \mathrm{C} \mathrm{NMR}$ $\left(\mathrm{MeOH}-d_{6}\right) \delta 18.5,19.5,22.0,23.2,26.1,29.3,41.3,52.5,60.5,69.6$, 174.1, 175.7; HRMS (CI) calcd for $\mathrm{C}_{12} \mathrm{H}_{25} \mathrm{~N}_{2} \mathrm{O}_{4} 261.1814\left([\mathrm{M}+\mathrm{H}]^{+}\right)$, found 261.1819 .

\section{Results and discussion}

The key strategy for the synthesis of bestatin and its analogs is how to prepare the threo- $\beta$-amino- $\alpha$-hydroxy acids moiety[14-17]. Recently, we have reported an efficient and stereoselective method for bestatin and its analog AHPBA-Val from chiral synthons, trans-oxazolidine methyl esters 2 , which are properly protected forms of threo- $\beta$-amino$\alpha$-hydroxy acids (Figure 3)[18]. In our previous study, bestatin and AHPBA-Val were synthesized efficiently with more than 20:1 stereoselectivity. Based on the successful synthesis of bestatin and AHPBA-Val, we wished to utilize the chiral key intermediates 2 for the synthesis of the isobutyl or isopropyl substituted bestatin analogs, 1a and $\mathbf{1 b}$.

In order to substitute the benzyl group in bestatin with an isobutyl or isopropyl group, we planned to prepare the desired trans-oxazolidines 2 from $N$-hydroxymethyl protected $\alpha$-amino aldehydes $4 \mathbf{a}$ and $\mathbf{4 b}$ via the stereoselective condensation reactions (Scheme 1). The basic hydrolysis of $\mathbf{2}$ and the following peptide coupling with L-Leu-OMe were expected to afford dipeptide derivatives $\mathbf{3}$, which would be readily converted to the desired dipeptides $\mathbf{1}$ with a global deprotection reaction.

The required starting compounds, two stable $\alpha$-amino aldehydes 4a and $\mathbf{4 b}$, were obtained from Boc-D-Leu-OH and Boc-D-Val-OH, respectively, according to the previously reported procedure [19-20]. In addition to a role of an $N$-hydroxymethyl group as a stabilizer of labile $\alpha$-amino aldehydes, it was also utilized to produce several trans-oxazolidines with a high stereoselectivity by an intramolecular conjugate addition[21-24]. For example, the intramolecular conjugate addition reactions between the $N$-hydroxymethyl group and the $\alpha, \beta$-unsaturated ester group resulted in the trans-oxazolidine derivatives with more than 10 to 1 stereoselecitvity, which were transformed into several natural 


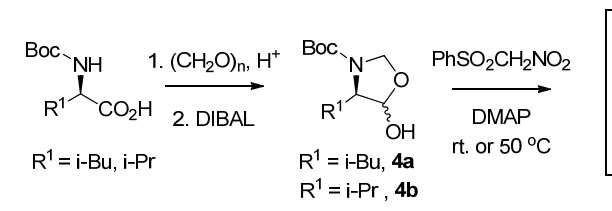

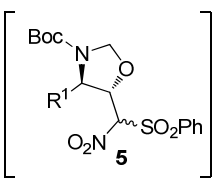

$\downarrow \mathrm{O}_{3}, \mathrm{MeOH}$

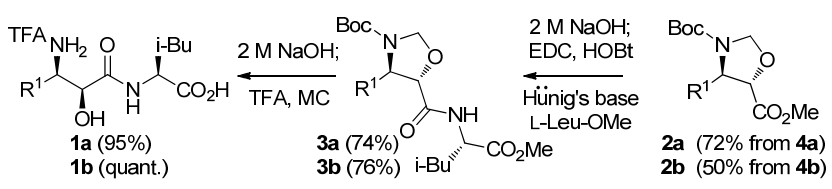

Scheme 2. Synthesis of new bestatin analogs, $1 \mathrm{a}$ and $1 \mathrm{~b}$.

or unnatural bioactive $\gamma$-amino- $\beta$-hydroxy acids, such as (-)-statine[21], 3 -aminodeoxystatin[22], threo- $\beta$-hydroxy-L-glutamic acid[23], and $(3 R, 4 S)$ AHPPA derivatives[24].

Contrast to the previous syntheses of $\gamma$-amino- $\beta$-hydroxy acids, the phenylsulfonylnitroolefin group was selected as a suitable Michael acceptor for the synthesis of $\beta$-amino- $\alpha$-hydroxy acids because the phenylsulfonylnitromethyl group on $\mathbf{5}$ (Scheme 2), resulted from the intramolecular conjugate addition of the $N$-hydroxymethyl group to the phenylsulfonylnitroolefin group of 7 (see below, Schemes 3), could be readily converted to the methyl ester group by ozonolysis in a methanolic solution via an oxidative Nef reaction[25].

Thus, the condensation reactions between configurationally stable $\alpha$ -amino aldehydes 4 and phenylsulfonylnitromethane $\left(\mathrm{PhSO}_{2} \mathrm{CH}_{2} \mathrm{NO}_{2}\right)$ under the weakly basic conditions[26] yielded the diastereomeric mixture of trans-oxazolidines $\mathbf{5}$, which were oxidized in-situ to give the desired $\beta$-amino- $\alpha$-hydroxy acid derivatives, $\mathbf{2} \mathbf{a}$ and $\mathbf{2} \mathbf{b}$, with an excellent stereoselectivity[18]. No minor cis-stereoisomers of $\mathbf{2 a}$ and $\mathbf{2 b}$ were observed on their ${ }^{1} \mathrm{H}$ NMR spectra. The desired absolute stereochemistry of $\mathbf{2 a}$ and $\mathbf{2} \mathbf{b}$ was derived from the corresponding D-amino acids, whereas the previous synthesis of threo- $\beta$-amino- $\alpha$-hydroxy acids from the L-amino acids gave the enantiomers of $\mathbf{2} \mathbf{a}$ and $\mathbf{2} \mathbf{b}[18]$.

Here, the different reactivity between $4 \mathbf{a}$ and $\mathbf{4 b}$ needs to be mentioned. Most of a valinal derivative $4 \mathbf{b}$ remained intact after the reaction with phenylsulfonylnitromethane at room temperature, whereas a leucinal derivative $4 \mathbf{a}$ smoothly reacted to produce the condensation product 5a under the same reaction conditions, which was converted into the corresponding methyl ester $\mathbf{2 a}$ in a $72 \%$ overall yield. The disappointing result with $\mathbf{4 b}$ was solved by simply raising the reaction temperature to $50{ }^{\circ} \mathrm{C}$, from which the methyl ester $\mathbf{2 b}$ was obtained in a $50 \%$ overall yield after the in-situ ozonolysis.

Formation of the condensation products $\mathbf{5}$ could be explained by the three cascade reactions as shown in Scheme 3[18]. The initial nitro-alcohols 6 resulted from the nitro-aldol reaction between 4 and $\mathrm{PhSO}_{2} \mathrm{CH}_{2} \mathrm{NO}_{2}$ were dehydrated in-situ to result in the phenylsulfonylnitroolefin intermediates 7 , which underwent the intramolecular conjugate addition to yield the cyclized adducts $\mathbf{5}$. The excellent stereoselectivity ( $>20: 1)$ for trans-oxazolidines $\mathbf{5}$ could be rationalized by the favored $H$-eclipsed conformation of 7[27-28]. The slower reactivity by the isopropyl analog $4 \mathbf{b}(\mathrm{R}=\mathrm{i}-\mathrm{Pr})$ might be also explained from the proposed mechanism (Scheme 3). The dehydration step of $\mathbf{6 b}(\mathrm{R}$

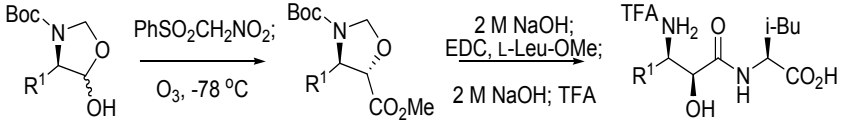

$$
\begin{aligned}
& R^{1}=\mathrm{i}-\mathrm{Bu}, \mathbf{4 a} \quad \mathrm{R}^{1}=\mathrm{i}-\mathrm{Bu}, \mathbf{2 a} \quad \mathrm{R}^{1}=\mathrm{i}-\mathrm{Bu}, 1 \mathrm{a}(51 \% \text { from } 4 \mathrm{a} \\
& R^{1}=\mathrm{i}-\mathrm{Pr}, \mathbf{4 b} \quad \mathrm{R}^{1}=\mathrm{i}-\mathrm{Pr}, \mathbf{2 b} \quad \mathrm{R}^{1}=\mathrm{i}-\mathrm{Pr}, \mathbf{1 b}(38 \% \text { from } \mathbf{4 b} \text { ) }
\end{aligned}
$$

Scheme 3. Proposed mechanism for trans-oxazolidines 5.

$=\mathrm{i}-\mathrm{Pr}$ ) with the bulky isopropyl group would be slower compared to that of $6 \mathbf{a}(\mathrm{R}=\mathrm{i}-\mathrm{Bu})$ because the increased allylic strains (both $\mathrm{A}^{1,3}$ and $A^{1,2}$ strains) between the $\mathrm{R}$ group the substituents $\left(-\mathrm{NO}_{2}\right.$ or $-\mathrm{SO}_{2} \mathrm{Ph}$, and $-\mathrm{CH}=\mathrm{C}$ ) on the double bond.

With trans-oxazolidine methyl esters $\mathbf{2 a}$ and $\mathbf{2 b}$ in hand that were properly protected forms of $\beta$-amino- $\alpha$-hydroxy acids, the peptide coupling of $\mathbf{2} \mathbf{a}$ and $\mathbf{2} \mathbf{b}$ with L-Leu-OMe afforded the corresponding dipeptide precursors, $\mathbf{3 a}$ and $\mathbf{3 b}$, in $74 \%$ and $76 \%$ yields, respectively, after the basic hydrolysis of methyl esters 2 to the corresponding carboxylic acids (not shown). Finally, the global deprotection under the sequential basic and acidic hydrolysis conditions produced the desired isobutyl or isopropyl substituted bestatin analogs, $\mathbf{1 a}$ and $\mathbf{1 b}$, in more than $95 \%$ yields.

\section{Conclusions}

We have reported an efficient and stereoselective synthesis of two new alkyl substituted bestatin analogs $\mathbf{1}$ from the appropriately protected $\beta$-amino- $\alpha$-hydroxy acid derivatives 2 , which were in turn successfully prepared with more than 20:1 stereoselectivity from stable $\alpha$ -amino aldehydes 4 via the stereoselective condensation reactions with phenylsulfonylnitromethane followed by the in-situ ozonolysis. Therefore, the isobutyl and isopropyl analogs of bestatin, $\mathbf{1 a}$ and $\mathbf{1 b}$, were reported for the first time. The new isobutyl and isopropyl analogs of bestatin, $\mathbf{1 a}$ and $\mathbf{1 b}$, were produced in overall $51 \%$ and $38 \%$ yields with high stereoselectivity from the corresponding protected $\alpha$ -amino aldehydes 4 in 6 steps, respectively. Further biological tests of the two bestatin analogs will be performed soon.

\section{Acknowledgement}

For the financial support, we would like to thank the BK-21 Plus Program and the Fundamental R\&D Program for Core Technology of Materials funded by the Ministry of Knowledge Economy. Y. Seo thanks the Global Ph.D. Fellowship that the National Research Foundation of Korea has conducted from 2011 (2011-0007775).

\section{References}

1. K. Ota, Review of ubenimex (Bestatin): clinical research, Biomed. Pharmacother., 45, 55-60 (1991).

2. O. A. Scornik and V. Botbol, Bestatin as an Experimental Tool in Mammals, Curr Drug Metab., 2, 67-85 (2001).

3. B. Bauvois and D. Dauzonne, Aminopeptidase-N/CD13 (EC 3.4.11.2) Inhibitors: Chemistry, Biological Evaluations, and Therapeutic Prospects, Med. Res. Rev., 1, 88-130 (2006). 
4. M. Wickstrom, R. Larsson, P. Nygren, and J. Gullbo, Aminopeptidase N (CD13) as a target for cancer chemotherapy, Cancer Sci., 102, 501-508 (2011).

5. H. Umezawa, T. Aoyagi, H. Suda, M. Hamada, and T. Takeuchi, Bestatin, an inhibitor of aminopeptidase B, produced by actinomycetes, J. Antibiot., 29, 97-99 (1976).

6. Y. Hirayama, S. Sakamaki, N. Takayanaqi, Y. Tsuji, T. Sagawa, H. Chiba, T. Matsunaga, and Y. Niitsu, Chemotheraphy with Ubenimex corresponding to patient age and organ disorder for 18 cases of acute myelogeneous leukemia in elderly patients-effects, complications and long-term survival, Gan To Kagaku Ryoho, 30, 1113-1118 (2003).

7. E. M. Gordon, J. D. Godfrey, N. G. Delaney, M. M. Asaad, D. V. Langen, and D. W. Cushman, Design of Novel Inhibitors of Aminopeptidases. Synthesis of Peptide-Derived Diamino Thiols and Sulfur Replacement Analogues of Bestatin, J. Med. Chem., 31, 2199-2211 (1988).

8. T. D. Ocain and D. H. Rich, Synthesis of Sulfur-Containing analogues of Bestatin. Inhibition of Aminopeptidases by $\alpha$ -Thiolbestatin Analogues, J. Med. Chem., 31, 2193-2199 (1988).

9. W. Yuan, B. Munoz, and C.-H. Wong, Development of Selective Tight-Binding Inhibitors of Leukotriene $\mathrm{A}_{4}$ Hydrolase, J. Med. Chem., 36, 211-220 (1993).

10. S. L. Harbeson and D. H. Rich, Inhibition of Arginine Aminopeptidase by Bestatin and Arphamenine Analogues Evidence for a New Mode of Binding to Aminopeptidases, Biochemistry, 27, 7301-7310 (1988).

11. M. B. Harbut, G. Velmourougane, G. Reiss, R. Chandramohanadas, and D. C. Greenbaum, Development of bestatin-based activity-based probes for metallo-aminopeptidases, Bioorg. Med. Chem. Lett., 18, 5932-5936 (2008).

12. T. Aoyagi, H. Tobe, F. Kojima, M. Hamada, T. Takeuchi, and H. Umezawa, Amastatin, an inhibitor of aminopeptidase A, Produced by actinomycetes, J. Antibiot., 31, 636-638 (1978).

13. B. R. Lampret, J. Kidrič, B. Kralj, L. Vitale, M. Pokorny, and M. Renko, Lapstatin, a new aminopeptidase inhibitor produced by Streptomyces rimosus, inhibits autogeneous aminopeptidase, Arch. Microbiol., 171, 397-404 (1999).

14. S. C. Bergmeier and D. M. Stanchina, Acylnitrene route to vicinal amino alcohols. Application to the synthesis of (-)-Bestatin and analogues, J. Org. Chem., 64, 2852-2859 (1999).

15. H. H. Wassermen, M. Xia, A. K. Petersen, M. R. Jorgensen and E. A. Curtis, Synthesis of the peptidic $\alpha$-hydroxy amides phebestin, probestin, and bestatin from $\alpha$-keto amide precursors, Tetrahedron Lett., 40, 6163-6166 (1999).

16. B. W. Lee, J. H. Lee, K. C. Jang, J. E. Kang, J. H. Kim, K.-M.
Park, and K. H. Park, Diastereoselective synthesis of syn-aminoalcohols via contributing $\mathrm{CH}-\pi$ interaction: simple synthesis of (-)-bestatin, Tetrahedron Lett., 44, 5905-5907 (2003).

17. N. Gogoi, J. Boruwa, and N. C. Barua, A total synthesis of (-)-bestatin using Shibasaki's asymmetric Henry reaction, Tetrahedorn Lett., 46, 7581-7582 (2005).

18. Y. Seo, H. Kim, D. W. Chae, and Y. G. Kim, N-Hydroxymethyl derivatives of $\alpha$-amino aldehydes used for the stereoselective syntheses of $\beta$-amino- $\alpha$-hydroxy acids, Tetrahedron: Asymmetry, 25, 625-631 (2014).

19. S. I. Hyun and Y. G. Kim, $N$-Hydroxymethyl group for configurationally stable $N$-alkoxycarbonyl $\alpha$-amino aldehydes [1], Tetrahedron Lett., 39, 4299-4302 (1998).

20. D. Yoo, J. S. Oh, D.-W. Lee, and Y. G. Kim, Efficient Synthesis of a Configurationally Stable L-Serinal Derivative, J. Org. Chem., 68, 2979-2982 (2003).

21. D. Yoo, J. S. Oh, and Y. G. Kim, The $N$-Hydroxymethyl group for Stereoselective Conjugate Addition: Application to the synthesis of (-)-statine, Org. Lett., 4, 1213-1215 (2002).

22. D. Yoo, S. Kwon, and Y. G. Kim, Application of the $N$-hydroxymethyl group to the stereoselective synthesis of $(3 S, 4 S)$-3-aminodeoxystatine derivatives, Tetrahedron: Asymmetry, 16, 3762-3766 (2005).

23. H. Kim, D, Yoo, S. Kwon, and Y. G. Kim, Efficient and stereoselective synthesis of threo- $\beta$-hydroxy-L-glutamic acid via a tandem (Z)-olefination-conjugate addition, Tetrahedron: Asymmetry, 20, 2715-2719 (2009).

24. D. Yoo, J. Song, M. S. Kang, E.-S. Kang, and Y. G. Kim, Stereodivergent approach to both syn- and anti- isomers of $\gamma$ -amino- $\beta$-hydroxy acids: $(3 S, 4 S)$ - and $(3 R, 4 S)$-AHPPA derivatives, Tetrahedron: Aymmetry, 22, 1700-1704 (2011).

25. B. M. Trost, R. Madsen, S. D. Guile, and B. Brown, Palladium-Catalyzed Enantioselective Synthesis of Carbanucleosides, J. Am. Chem. Soc., 122, 5947-5956 (2000).

26. For another in-situ formation of the phenylsulfonylnitroolefin group under strongly basic conditions, see: P. A. Wade, J. K. Murray, S. Shah-Patel, B. A. Palfey, and P. J. Carroll, Tandem Nitroaldol-Dehydration Reactions Employing the Dianion of Phenylsulfonylnitromethane, J. Org. Chem., 65, 7723-7730 (2000).

27. J. Jeon, S.-H. Kim, J. H. Lee, J. S. Oh, D. Y. Park, and Y. G. Kim, Anti-Selective Dihydroxylation Reactions of Monosubstituted and $(E)$-Ester Conjugated Allylic Amines by Bulkyl our group, Bull. Korean Chem. Soc., 30, 1003 (2009).

28. J. Jeon, N. Shin, and Y. G. Kim, Stereocontrolled Dihydroxylation Reactions of Acyclic Allylic Amines, Appl. Chem. Eng., 25, 437-446 (2014). 